\title{
Genetic Parameters Exploration of Pea Genotypes using Two Environmental Conditions
}

\author{
Lokesh Gour*, R.K. Dubey, P.K. Moitra, S.K. Singh, S.S. Shukla and S. Tiwari \\ Department of Plant Breeding and Genetics, Jawaharlal Nehru Krishi Vishwa Vidyalaya, \\ Jabalpur (M.P.), 482004, India \\ *Corresponding author
}

\begin{tabular}{|l|}
\hline Ke y w or d s \\
Variability, \\
Environment, GCV \\
and PCV
\end{tabular}

\section{A B S T R A C T}

Pisum sativum L. had been used as a good source of nutritious food. The estimate of genetic variability was observed for twenty three traits on 60 genotypes. The ANOVA indicated that the mean sum of squares due to genotypes were highly significant for days to first flower opening and days to fifty percent flowering, respectively in all the environmental conditions. High magnitude of phenotypic coefficient of variation was observed than the genotypic coefficient of variation for all the characters under study. High genotypic and phenotypic coefficient of variations were exhibited for number of primary branches per plant, number of secondary branches per plant, plant height, number of node per plant, number of effective node per plant, pod bearing length, number of pod per plant, number of effective pod per plant, number of seed per plant, biological yield, biological yield per plant, seed yield per plant and reducing sugar in both of environments. The above finding revealed the presence of substantial amount of genetic variability for the traits, which exhibited high magnitudes as well as less influence of environment on the expression of concerned traits. Day to first flower opening, days to fifty per cent flowering, hundred seed weight, harvest index, total sugar, non-reducing sugar and ash exhibited moderate genotypic and phenotypic coefficient variation in both of environments except number of seed per pod and protein content. Low genotypic and phenotypic coefficient of variation was observed for days to maturity and pod length in both of two environments, this reveled high influence of environment.

\section{Introduction}

Pea (Pisum sativum L.) had been used as a good source of nutritious food since Neolithic times (Majid et al., 2017). It is cultivated in about more than 50 countries in the arid, semiarid and temperate regions, whereas; about $90 \%$ of world field pea is grown under rainfed conditions (FAO STAT, 2011). Pea has various uses in consumption aspects and fulfils the dietary nutrition. Accordingly, garden pea used for table purpose, hence harvest at green pod condition. Field pea is used as dry, whole or split as dal or used as flour (Besan) for various food preparations (Datta and Singh, 2015). Dry pea seed has high protein $(22.5 \%)$ with all the essential amino acids. It also contains $56.5 \%$ carbohydrate, $1.1 \%$ fat, $2.2 \%$ minerals, $4.5 \%$ fiber and important vitamins like vit $\mathrm{B}_{1}$ and $\mathrm{B}_{5}$ 
(AICRP MULLARP and Sahoo, 2018). Now a days, protein markets are shifting away from dairy, egg, soy, and wheat ingredients toward alternative sources (e.g., pea) due to consumers' perceived fears about consuming animal-derived products, dietary choices based on religious or moral preferences, allergenicity and genetic modification (Toews and Wang, 2013). Legume proteins are dominated by two classes of proteins, namely albumins and globulins (Shelepina et al., 2016), which comprise 10-20\% and $70-80 \%$ of the total protein found within the seed. It is well known that the chemical content of pea seeds can vary due to differences in climate, soil, varieties and agronomic practices. Field pea resulted to have variation in chemical components, when grown in various parts of the world (Barac et al., 2010). Chemical analysis is necessary for determination of the quality traits, like; protein content, total sugars content, reducing and non reducing sugars content and ash content (Červenski et al., 2017 and Sahoo, 2018).

Being third most important pulse crop in India, the pea has quite low productivity in comparison to other growing countries. This may be due to lack of improved high yielding varieties, narrow genetic base of released varieties, use of poor quality seeds and nonavailability of irrigation (Singh, 2002). Genotypes also respond to changes in environmental conditions such as temperature, rainfall, soil type, moisture and so on (Acikgoz et al., 2009). A critical analysis of genetic variability is a pre-requisite for initiating any crop improvement programme and for adopting the appropriate selection techniques (Patel, 2016). The essential feature is the partitioning of total variation into genotypic and environmental components and determines the magnitude of these components for various traits assessment of the type of genetic variation and thus helps in deciding a breeding procedure for the genetic improvement of a trait.
Considering the importance of pea as a economic value in the agriculture throughout the world and also the genetic components contributing their role in the high yield and quality. The present investigation was conducted to study the variation under the genotypes over two environments in this crop.

\section{Materials and Methods}

The details of the materials used and methodologies adopted and applied in the present investigation are illustrated here.

\section{Experimental material and management}

Experimental material consists of sixty genotypes of field pea included was received from Field Pea Improvement Project, Department of Plant Breeding and Genetics, COA, Jabalpur and AICRP on MULLaRP, IIPR Kanpur.

The experiment involved field and laboratory experiments. The field experiment was conducted for one year 2016-17 during rabi season but this 60 germplasm lines (Table 1) were quantitatively observed as normal $(13 / 11 / 2016$ - E1) and late (28/11/2016 - E2) sown conditions at Seed Breeding Farm, College of Agriculture, Jabalpur (M.P.). The laboratory (quality) work was carried out in the Quality laboratory of Department of Plant Breeding and Genetics, College of Agriculture, Jabalpur (M.P.). The recommended package and practices were followed to raise the healthy crop.

\section{Observations recorded}

\section{Quantitative traits}

Sixty pea germplasms were observed for 18 quantitative traits assessment. Five competitive plants were randomly selected from each plot in every replication to record 
various observations on the following characters except days to first flower opening, days to $50 \%$ flowering and days to maturity, which were recorded on plot basis as given in DUS guidelines.

\section{Quality analysis}

The sugar content of the samples was determined by the method as described by Ranganna (1986). The protein content in samples was determined by using conventional Micro-Kjeldhal digestion and distillation procedure as given in AOAC (1984). The ash content in the sample was estimated according to AOAC (1992).

\section{Statistical methodology}

The data obtained in respect of all the characters studied were subjected to the following analyses.

\section{Analysis of variance}

The data based on the mean of individual plants selected for observation were statistically analyzed to find out overall total variability present in the material under study for each character taking all the populations. The first and foremost step is to carry out analysis of variance (Table 2) to test the significance of differences among the populations.

The analysis of variance was carried out as per methods suggested by Panse and Sukhatme (1967), the skeleton of analysis of variance used was as follows-

\section{Genotypic and phenotypic coefficient of variances}

Phenotypic and genotypic coefficient of variances were estimated using the following formula-

\section{Genotypic coefficient of variation (GCV \%) (Burton 1952)}

$\mathrm{GCV} \%=\frac{\sigma_{\mathrm{g}}}{\overline{\overline{\mathrm{x}}}} \times 100$

Where, $\sigma_{\mathrm{g}}=\sqrt{\sigma_{g}^{2}}$

Phenotypic coefficient of variation (PCV \%) (Burton 1952)

Since, $\mathrm{PCV}=\frac{\frac{\sigma \mathrm{p}}{\overline{\mathrm{X}}} \times 100}{}$

Where, $\sigma_{\mathrm{p}}=\sqrt{\sigma_{p}^{2}}$

Where,

$\sigma_{p}^{2}=$ Phenotypic variance

$\sigma_{\mathrm{p}}=$ Phenotypic standard deviation

$\sigma_{\mathrm{g}}{ }^{2}=$ Genotypic variance

$\sigma_{\mathrm{g}}=$ Genotypic standard deviation

$\overline{\mathrm{X}}=$ General Mean

The estimates of PCV and GCV were classified as low, moderate and high according to Sivasubramanian and Madhavamenon (1973).

$<10$ per cent $=$ low

10-20 per cent $=$ moderate

$>20$ per cent $=$ high

\section{Results and Discussion}

\section{Genetic variability}

The breeding programme of any crop mainly depends upon the magnitude of genetic variability. Sixty genotypes were evaluated for 23 quantitative and quality characters related to grain yield, yield components and grain quality. Analysis of variance refers to the observable differences in individuals for a 
particular trait. To know the extent of variation for observed traits among the genotypes of pea, analysis of variance under two environmental conditions was performed. The mean sums of square were significant in almost all the genotypes for different characters, which revealed that there was considerable genetic variability present amongst the material under study (Table 3 ).

\section{E1}

Result of analysis of variance indicated that the mean sum of square due to genotypes were significant for all the characters, indicating the presence of genetic variability in the material under study, mean sum of square was maximum and highly significant for number of seed per plant (gm) and minimum for number of primary branches per plant.

The magnitude of variability in decreasing order for other traits were as follows, plant height $(\mathrm{cm})$, number of node per plant, pod bearing length, biological yield per plant (gm), number of pod per plant, number of effective pod per plant, number of effective node per plant, days to fifty percent flowering, days to maturity, days to first flower opening, seed yield per plant (gm), harvest index, 100 seed weight (gm), protein content, total sugar, nonreducing sugar, number of secondary branching per plant, number of seed per pod, reducing sugar, ash content and pod length.

\section{E2}

Considerable amount of variability was observed for all characters as evident from significant mean sum of square. Maximum variability was observed for plant height $(\mathrm{cm})$ and minimum for pod length $(\mathrm{cm})$.

The magnitude of variability in decreasing order for other traits were as follows, number of seed per plant, number of node per plant, pod bearing length, number of pod per plant, biological yield per plant (gm), days to first flower opening, days to fifty percent flowering, number of effective pod per plant, days to maturity, number of effective node per plant, harvest index, seed yield per plant (gm), 100 seed weight (gm), protein content, number of secondary branching per plant, total sugar, non-reducing sugar, number of primary branches per plant, reducing sugar, ash content and number of seed per pod.

\section{Genotypic and phenotypic coefficient of variation (GCV and PCV \%)}

Genotypic variation is the heritable portion of phenotypic or total variation. It gives the variation between genotypes.

Environmental variation is the non-heritable portion of observable variation. Phenotypic variance refers to the total variation in a population. It is sum of genotypic and environment variance.

Genotypic and phenotypic coefficients of variation (GCV and PCV) were classified as low, moderate and high according to Sivasubramanian and Madhavamenon (1973).

$<10$ per cent $=$ low

10-20 per cent $=$ moderate

$>20$ per cent $=$ high

The estimation of genotypic and phenotypic coefficient of variation (GCV and PCV) for yield and yield attributing traits over different environments and pooled over environments were computed and results are presented in Table 4.

Result indicated that the value of phenotypic coefficient of variation were higher than the genotypic coefficient of variation for all the characters in E1 and E2 as well as pooled data over three environments. 
Table.1 List of genotypes uses in the experiment

\begin{tabular}{|c|c|c|c|}
\hline S. No. & Name of genotypes & S. No. & Name of genotypes \\
\hline 1. & B-22 & 31. & PP-96 \\
\hline 2. & Shikha & 32. & HUP-2 \\
\hline 3. & Rachna & 33. & HUDP-15 \\
\hline 4. & Jayanti & 34. & FP $14-76$ \\
\hline 5. & VL-1 & 35. & FP 14-82 \\
\hline 6. & VL-3 & 36. & Kalamatar \\
\hline 7. & P-3 & 37. & FP $14-65$ \\
\hline 8. & RP-3 & 38. & FP 14-67 \\
\hline 9. & DDR-23 & 39. & FP $14-85$ \\
\hline 10. & DDR-39 & 40. & FP 14-86 \\
\hline 11. & DDR-52 & 41. & FP $14-90$ \\
\hline 12. & DDR-55 & 42. & FP 14-36 \\
\hline 13. & JP-885(Purple) & 43. & FP 14-41 \\
\hline 14. & FP 9-540 & 44. & FP $14-44$ \\
\hline 15. & FP 7-562 & 45. & FP 14-46 \\
\hline 16. & KPMR-302 & 46. & FP $14-50$ \\
\hline 17. & KPMR-504 & 47. & FP 14-51 \\
\hline 18. & KPMR-402 & 48. & FP $14-54$ \\
\hline 19. & KPMR-420 & 49. & FP 14-56 \\
\hline 20. & KPMR-423 & 50. & FP 14-15 \\
\hline 21. & KPMR-485 & 51. & FP 14-23 \\
\hline 22. & KPMR-144 & 52. & FP 14-24 \\
\hline 23. & KPMR-327 & 53. & FP 14-26 \\
\hline 24. & NDVP-20 & 54. & FP 14-30 \\
\hline 25. & LEP-227 & 55. & FP 14-32 \\
\hline 26. & LEP-260 & 56. & FP 14-33 \\
\hline 27. & JFP-27 & 57. & FP 14-34 \\
\hline 28. & JFP 99-25 & 58. & FP 14-4 \\
\hline 29. & PP-14 & 59. & FP 14-5 \\
\hline 30. & PP-86 & 60. & FP 14-13 \\
\hline
\end{tabular}

Table.2 ANOVA table for randomized complete block design

\begin{tabular}{|c|c|c|c|c|c|}
\hline $\begin{array}{l}\text { Source of } \\
\text { variation }\end{array}$ & d.f. & $\begin{array}{l}\text { Sum of } \\
\text { squares }\end{array}$ & $\begin{array}{c}\text { Mean } \\
\text { squares }\end{array}$ & F ratio & $\begin{array}{l}\text { Expected mean } \\
\text { squares }\end{array}$ \\
\hline Replication & $(\mathrm{r}-1)$ & S.Sr & $\mathrm{Mr}$ & $\mathrm{Mr} / \mathrm{Me}$ & \\
\hline Genotypes & $(g-1)$ & S.Sg & $\mathrm{Mg}$ & $\mathrm{Mg} / \mathrm{Me}$ & $\sigma^{2}{ }^{2}+r \sigma_{g}^{2}$ \\
\hline Error & $(\mathrm{r}-1)(\mathrm{g}-1)$ & S.Se & Me & & $\sigma_{\mathrm{e}}^{2}$ \\
\hline Total & $(\mathrm{rg}-1)$ & & & & \\
\hline
\end{tabular}

Where, $r=$ number of replications; $g=$ number of genotypes; $\sigma^{2}{ }_{e}=$ error mean square; $\sigma_{g}^{2}=$ genotypic mean square 
Table.3 (a) Analysis of variances for yield and yield attributing traits of pea genotypes over environments

\begin{tabular}{|c|c|c|c|c|c|c|c|c|c|c|}
\hline \multirow{2}{*}{$\begin{array}{l}\text { Source of } \\
\text { variation }\end{array}$} & \multirow[t]{2}{*}{ D.F. } & \multirow[t]{2}{*}{ Env. } & \multicolumn{8}{|c|}{ Mean sums of square } \\
\hline & & & DFFO & DFF & DM & NPBPP & NSBPP & PH & NNPP & NENPP \\
\hline \multirow[t]{2}{*}{ Replication } & 2 & E1 & $15.6956^{* *}$ & $16.4439 * *$ & $15.8162 * *$ & $0.0298 * *$ & $0.0262 *$ & $13.6595 * *$ & 2.1201 & $0.6990 *$ \\
\hline & & E2 & $3.6687 * *$ & $4.0160 *$ & $2.8200 *$ & $0.0127 *$ & $0.0565 * *$ & $4.5522 *$ & $7.7339 * *$ & 0.6640 \\
\hline \multirow[t]{2}{*}{ Genotype } & 59 & E1 & $89.8695 * *$ & $138.1747 * *$ & $106.4753^{* *}$ & $0.4582 * *$ & $2.7176 * *$ & $1695.0947 * *$ & $1576.3399 * *$ & $141.9854 * *$ \\
\hline & & E2 & $178.4603 * *$ & $177.9855^{* *}$ & $170.8535^{* *}$ & $1.0800 * *$ & $5.7850 * *$ & $3886.4123 * *$ & $1863.6612 * *$ & $145.4675^{* *}$ \\
\hline \multirow[t]{2}{*}{ Error } & 118 & E1 & 0.4193 & 0.4388 & 0.4837 & 0.0024 & 0.0064 & 0.9153 & 0.9411 & 0.1952 \\
\hline & & E2 & 0.6937 & 1.0732 & 0.8303 & 0.0039 & 0.0098 & 1.1155 & 1.3052 & 0.2344 \\
\hline
\end{tabular}

Table.3 (b) Analysis of variances for yield and yield attributing traits of pea genotypes over environments

\begin{tabular}{|c|c|c|c|c|c|c|c|c|c|c|}
\hline \multirow[t]{2}{*}{ Source of variation } & \multirow[t]{2}{*}{ D.F. } & \multirow[t]{2}{*}{ Env. } & \multicolumn{8}{|c|}{ Mean sums of square } \\
\hline & & & PBL & NPPP & NEPPP & PL & NSPP & NSPPIt & $100 \mathrm{SW}$ & BYPP \\
\hline \multirow[t]{2}{*}{ Replication } & 2 & E1 & $10.8284 * *$ & $1.2602 * *$ & 0.1495 & 0.0058 & 0.0025 & 0.6773 & 0.0208 & 3.4162 \\
\hline & & E2 & $2.9677 *$ & $7.4198 * *$ & $1.5726 *$ & $0.0336 * *$ & $0.0092 *$ & 2.3268 & 0.0412 & $2.4974^{*}$ \\
\hline \multirow[t]{2}{*}{ Genotype } & 59 & E1 & $468.2447 * *$ & $300.0937 * *$ & $185.4628 * *$ & $0.7446 * *$ & $1.4933 * *$ & $3674.6588 * *$ & $12.8995 * *$ & $311.1334 * *$ \\
\hline & & $\mathbf{E} 2$ & $1210.7972 * *$ & $282.0599 * *$ & $171.1770 * *$ & $0.6280 * *$ & $0.6741 * *$ & $2939.3727 * *$ & $17.7053 * *$ & $234.9978 * *$ \\
\hline \multirow[t]{2}{*}{ Error } & 118 & E1 & 0.3638 & 0.2374 & 0.2012 & 0.0247 & 0.0221 & 0.2843 & 0.0814 & 1.2737 \\
\hline & & E2 & 0.8738 & 1.0219 & 0.4490 & 0.0049 & 0.0024 & 1.0832 & 0.0158 & 0.5467 \\
\hline
\end{tabular}

Table.3 (c) Analysis of variances for yield and yield attributing traits of pea genotypes over environments

\begin{tabular}{|c|c|c|c|c|c|c|c|c|c|}
\hline \multirow{2}{*}{$\begin{array}{l}\text { Source of } \\
\text { variation }\end{array}$} & \multirow[t]{2}{*}{ D.F. } & \multirow[t]{2}{*}{ Env. } & \multicolumn{7}{|c|}{ Mean sums of square } \\
\hline & & & HI & SYPP & TS & $\mathbf{R S}$ & NRS & PROTEIN & ASH \\
\hline \multirow{2}{*}{ Replication } & 2 & E1 & 1.4141 & 0.0688 & 0.0042 & 0.0066 & 0.0005 & 0.0057 & 0.0217 \\
\hline & & E2 & $1.7702 * *$ & 0.0167 & 0.0023 & 0.0013 & 0.0005 & 0.0003 & 0.0060 \\
\hline \multirow[t]{2}{*}{ Genotype } & 59 & E1 & $67.7260 * *$ & $76.3102 * *$ & $5.0345^{* *}$ & $0.8307 * *$ & $3.0094 * *$ & $11.1342 * *$ & $0.8097 * *$ \\
\hline & & E2 & $75.0750 * *$ & $50.5463 * *$ & $4.8547 * *$ & $0.7426 * *$ & $3.0683^{* *}$ & $11.1280^{* *}$ & $0.6775^{* *}$ \\
\hline \multirow[t]{2}{*}{ Error } & 118 & E1 & 0.9493 & 0.0749 & 0.0172 & 0.0091 & 0.0258 & 0.0212 & 0.0092 \\
\hline & & E2 & 0.3155 & 0.0342 & 0.0112 & 0.0054 & 0.0155 & 0.0071 & 0.0060 \\
\hline
\end{tabular}

$*$ and $* *$ indicate level of significant at $5 \%$ and $1 \%$, respectively 
Table.4 GCV\% and PCV\% for yield and yield attributing traits of pea genotypes over environments

\begin{tabular}{|c|c|c|c|c|}
\hline Traits & \multicolumn{2}{|c|}{ GCV\% } & \multicolumn{2}{c|}{ PCV\% } \\
\hline & E1 & E2 & E1 & E2 \\
\hline DFFO & 10.234 & 13.362 & 10.305 & 13.440 \\
\hline DFF & 11.253 & 12.109 & 11.307 & 12.219 \\
\hline DM & 6.595 & 8.078 & 6.640 & 8.137 \\
\hline NPBPP & 22.222 & 31.469 & 22.398 & 31.641 \\
\hline NSBPP & 22.882 & 34.012 & 22.962 & 34.099 \\
\hline PH & 25.096 & 35.791 & 25.116 & 35.807 \\
\hline NNPP & 36.638 & 37.805 & 36.671 & 37.845 \\
\hline NENPP & 39.454 & 40.708 & 39.536 & 40.806 \\
\hline PBL & 22.648 & 37.653 & 22.674 & 37.694 \\
\hline NPPP & 36.474 & 36.716 & 36.517 & 36.916 \\
\hline NEPPP & 39.182 & 35.574 & 39.246 & 35.714 \\
\hline PL & 8.516 & 8.199 & 8.942 & 8.295 \\
\hline NSPP & 14.115 & 9.823 & 14.429 & 9.875 \\
\hline NSPPIt & 35.868 & 34.146 & 35.872 & 34.165 \\
\hline 100 SW & 12.993 & 15.024 & 13.116 & 15.044 \\
\hline BYPP & 24.602 & 23.713 & 24.753 & 23.796 \\
\hline HI & 12.758 & 13.344 & 13.027 & 13.428 \\
\hline SYPP & 32.619 & 29.302 & 32.667 & 29.332 \\
\hline TS & 16.449 & 15.702 & 16.533 & 15.756 \\
\hline RS & 32.937 & 32.849 & 33.575 & 33.572 \\
\hline NRS & 14.950 & 14.546 & 15.142 & 14.657 \\
\hline PROTEIN & 9.564 & 9.634 & 9.592 & 9.643 \\
\hline ASH & 18.815 & 17.990 & 19.135 & 18.231 \\
\hline & & & & \\
\hline
\end{tabular}

Table.5 Ranking of mean sum of squares due to genotypes as per their values for some of traits

\begin{tabular}{|l|}
\hline Traits \\
\hline NSPPIt \\
\hline PH \\
\hline NNPP \\
\hline PBL \\
\hline BYPP \\
\hline NPPP \\
\hline NEPPP \\
\hline NENPP \\
\hline DFF \\
\hline DM \\
\hline DFFO \\
\hline
\end{tabular}

\begin{tabular}{|c|c|}
\hline E1 & E2 \\
\hline I & II \\
\hline II & I \\
\hline III & III \\
\hline IV & IV \\
\hline VI & VI \\
\hline VII & V \\
\hline VIII & IX \\
\hline IX & XI \\
\hline X & VIII \\
\hline XI & X \\
\hline
\end{tabular}


Table.6 Summary of characters showing combinations of GCV and PCV

\begin{tabular}{|c|c|c|c|c|c|c|c|c|}
\hline \multicolumn{2}{|c|}{ High PCV and GCV } & \multicolumn{3}{|c|}{ Moderate PCV and GCV } & \multicolumn{3}{|c|}{ Low PCV and GCV } \\
\hline Traits & E1 & E2 & Traits & E1 & E2 & Traits & E1 & E2 \\
\hline NPBPP & $\sqrt{ }$ & $\sqrt{ }$ & DFFO & $\sqrt{ }$ & $\sqrt{ }$ & DM & $\sqrt{ }$ & $\sqrt{ }$ \\
\hline NSBPP & $\sqrt{ }$ & $\sqrt{ }$ & DFF & $\sqrt{ }$ & $\sqrt{ }$ & PL & $\sqrt{ }$ & $\sqrt{ }$ \\
\hline PH & $\sqrt{ }$ & $\sqrt{ }$ & NSPP & $\sqrt{ }$ & & NSPP & & $\sqrt{ }$ \\
\hline NNPP & $\sqrt{ }$ & $\sqrt{ }$ & $\mathbf{1 0 0}$ SW & $\sqrt{ }$ & $\sqrt{ }$ & PROTEIN & $\sqrt{ }$ & $\sqrt{ }$ \\
\hline NENPP & $\sqrt{ }$ & $\sqrt{ }$ & HI & $\sqrt{ }$ & $\sqrt{ }$ & & & \\
\hline PBL & $\sqrt{ }$ & $\sqrt{ }$ & TS & $\sqrt{ }$ & $\sqrt{ }$ & & & \\
\hline NPPP & $\sqrt{ }$ & $\sqrt{ }$ & NRS & $\sqrt{ }$ & $\sqrt{ }$ & & & \\
\hline NEPPP & $\sqrt{ }$ & $\sqrt{ }$ & PROTEIN & & & & & \\
\hline NSPPIt & $\sqrt{ }$ & $\sqrt{ }$ & ASH & $\sqrt{ }$ & $\sqrt{ }$ & & & \\
\hline BYPP & $\sqrt{ }$ & $\sqrt{ }$ & & & & & & \\
\hline SYPP & $\sqrt{ }$ & $\sqrt{ }$ & & & & & & \\
\hline RS & $\sqrt{ }$ & $\sqrt{ }$ & & & & & & \\
\hline
\end{tabular}

DFFO - days to first flower opening, DFF- days to fifty percent flowering, DM- days to maturity, NPBPP- number of primary branches per plant, NSBPP- number of secondary branches per plant, PH- plant height, NNPP- number of node per plant, NENPP- number of effective node per plant, PBL-pod bearing length, NPPP- number of pod per plant, NEPPP- number of effective pod per plant, PL- pod length, NSPP- number of seed per pod, NSPPlt- number of seed per plant, $100 \mathrm{SW}$ - hundred seed weight, BYPP- biological yield per plant, HI- harvest index, SYPP- seed yield per plant.

\section{E1}

High genotypic and phenotypic coefficient of variation was observed for number of effective node per plant (39.454 and 39.536), number of effective pod per plant (39.182 and $39.246)$, number of node per plant $(36.638$ and 36.671$)$, number of pod per plant (36.474 and 36.517$)$, number of seed per plant $(35.868$ and 35.872), reducing sugar (32.937 and $33.575)$, seed yield per plant (32.619 and 32.667), plant height (25.096 and 25.116), biological yield per plant (24.602 and 24.753), number of secondary branching per plant (22.882 and 22.962), pod bearing length (22.648 and 22.674) and number of primary branching per plant (22.222 and 22.398).

However, moderate GVC and PCV were recorded for ash content (18.815 and 19.135), total sugar (16.449 and 16.533), non-reducing sugar (14.950 and 15.142), number of seed per pod (14.115 and 14.429), hundred seed weight (12.993 and 13.116), harvest index (12.758 and 13.027), days to fifty percent flowering (11.253 and 11.307) and days to first flower opening (10.234 and 10.305), whereas, low GVC and PCV were recorded for protein content (9.564 and 9.592), pod length (8.516 and 8.942) and days to maturity (6.595 and 6.640).

\section{E2}

High genotypic and phenotypic coefficient of variation was exhibited by number of effective node per plant (40.708 and 40.806) followed by number of node per plant $(37.805$ and 37.845), pod bearing length (37.653 and 37.694), number of pod per plant (36.716 and 36.916), plant height (35.791 and 35.807), number of effective pod per plant (35.574 and 35.714 ), number of seed per plant (34.146 and 34.165), number of secondary branches per plant (34.012 and 34.099), reducing sugar (32.849 and 33.572), number of primary 
branches per plant (31.469 and 31.641), seed yield per plant (29.302 and 29.332) and biological yield per plant (23.713 and 23.796).

However, ash content (17.990 and 18.231), total sugar (15.702 and 15.756), hundred seed weight (15.024 and 15.044), non-reducing sugar (14.546 and 14.657), days to first flower opening (13.362 and 13.440), harvest index (13.344 and 13.428) and days to fifty percent flowering (12.109 and 12.219) showed medium genotypic and phenotypic coefficient of variation.

The low GCV and PCV \% were observed for number of seed per pod (9.823 and 9.875), protein content (9.634 and 9.643), pod length (8.199 and 8.295) and days to maturity (8.078 and 8.137).

\section{Parameters of genetic variability}

\section{Genetic variability}

The estimate of genetic variability was observed for twenty three traits on 60 genotypes. The ANOVA indicated that the mean sum of squares due to genotypes were highly significant for days to first flower opening, days to fifty percent flowering, days to maturity, number of primary branches per plant, number of secondary branches per plant, plant height, number of node per plant, number of effective node per plant, pod bearing length, number of pod per plant, number of effective pod per plant, pod length, number of seed per pod, number of seed per plant, 100 seed weight, biological yield per plant, harvest index, seed yield per plant, total sugar, reducing sugar, non-reducing sugar, protein content and ash in all the environmental conditions. These findings are supported by Sahoo, 2018, Jaiswal et al., (2015), Katoch et al., (2016), Kumar et al., (2017) and Toppo, 2015, whereas, Patel, 2017 also supported all the characters except, days to $50 \%$ flowering, number of primary branches per plant, number of seeds per pod and pod length for which non-significant differences were observed.

On the basis of the value of mean sum of square due to genotype the traits is ranked in Table 5. However, on contrary to the present result, non-significant difference for plant height among 50 Ethiopian grasspea accessions was also reported by Wuletaw and Endashaw (2003). This difference may be due to differences in accessions and environmental conditions of the research sites used by the researchers.

\section{Phenotypic and genotypic coefficient of variation}

Phenotypic and genotypic coefficient of variations was computed for all the twenty three traits. Therefore, these parameters were made unit free by estimating phenotypic coefficient of variation (PCV) and genotypic coefficient of variation (GCV). As GCV represents the heritable genetic component of the total variation, it would be more appropriate to use this parameter for comparing variability of different characters.

In the present study, the phenotypic coefficient of variation was greater than genotypic coefficient of variation for all the traits in both the environments (Patel, 2017). High magnitude of phenotypic coefficient of variation was observed than the genotypic coefficient of variation for all the 23 characters under study.

High genotypic and phenotypic coefficient of variations were exhibited for number of primary branches per plant, number of secondary branches per plant, plant height, number of node per plant, number of effective node per plant, pod bearing length, number of 
pod per plant, number of effective pod per plant, number of seed per plant, biological yield, biological yield per plant, seed yield per plant and reducing sugar in both of environments. The above finding revealed the presence of substantial amount of genetic variability for the traits, which exhibited high magnitudes as well as less influence of environment on the expression of concerned traits. Similar results for different characters have also been reported by Saxesena et al., (2014); Katiyar et al., (2014); Ahmad et al., (2014); Kosev, (2015); Patel, 2017 and Sahoo, 2018.

Day to first flower opening, days to fifty per cent flowering, hundred seed weight, harvest index, total sugar, non-reducing suagr and ash exhibited moderate genotypic and phenotypic coefficient variation in both of environments except number of seed per pod and protein content. Mishra (2014), Jeberson et al., (2016) and Sahoo, (2018) also reported similar result. Number of seed per pod in E1 exhibited moderate value of genotypic and phenotypic coefficient variation but it found low value of genotypic and phenotypic coefficient variation in E2.

Low genotypic and phenotypic coefficient of variation was observed for days to maturity and pod length in both of two environments (Table 6). Yadav (2013), Saxena et al., (2014) and Sahoo, 2018 supported similar result for days to maturity. But number of seed per pod found low genotypic and phenotypic coefficient of variation in E2 whereas, protein content found low GCV and PCV in both of two environments.

In last it were revealed in this study that the presence of substantial amount of genetic variability like, high variability, GCV and PCV for various traits, which exhibited high magnitudes as well as less influence of environment on the expression of concerned traits. So selection of such traits for heterotic group development will be useful.

\section{References}

Açıkgöz, E., Sincik, M., Karasu, A., Töngel, O., Wietgrefe, G., Bilgili, U., Albayrak, S., Turan, Z.M., Göksoy, A.T. (2009). Forage soybean production for seed in Mediterranean environments. Field Crop. Res., 110: 213-218.

Ahmad, H.B., Rauf, Rafiq M. S. Ch., Mohsin, A.U. and Iqbal, A. (2014). Estimation of Genetic Variability In pea (Pisum sativum L.). Journal of global innovation in agricultural and social sciences 2 (2): 62-64.

AICRP

MULLaRPhttp://www.aicrpmullarp.res.in

AOAC, (1984). Official method of Analysis 14th Edition. Association of official analytical Chemists. Virginia, USA.

Barac, M., Pesic, M., Stanojevic, S., Macej, O., Ristic, N., Cabrilo, S., Zilic, S. (2010). Profile and functional properties of seed proteins from six pea (Pisum sativum) genotypes. International Journal of Molecular Sciences; 11(12):4973-90.

Burton, G.W. (1952). Quantitative inheritance in grasses Proceedings 6th International, grassland congress 1: 227-283.

Cervenski, J., Danojevic, D., and Savic, A. (2017). Chemical composition of selected winter green pea (Pisum sativum L.) genotypes. Journal of Serbian Chemistry Society 82(11):1237-1246.

Datta, S.K., Singh, B.B. (2015). Production and productivity of pulses: Indian perspectives. Pulses handbook. Pp: 34 .

FAO. (2011). FAO Statistical division, http://www.faostat.fao.org

Jaiswal, N.K., Gupta, A.K., Dewangan, H. and Lavanya, G.R. (2015). Genetic 
variability analysis in field pea (Pisum sativum L.). Int. J. Sci. Res., 4 (1).

Jeberson, M.S., Shashidhar, K.S., and Iyanar, K. (2016). Estimation of genetic variability, expected genetic advance, correlation and path analysis in field pea (Pisum sativum L.) Electronic Journal of Plant Breeding, 7(4): 1074-1078.

Katiyar, S., Singh, H.C., Verma, M.C., Katiyar, M., and Singh, R.K. (2014). Genetic Analysis for of Heterotic Crosses in Table Pea (Pisum sativum L.) Trends in Biosciences; 7(9):733735 .

Katoch, V., Singh, P., Mayanglambam, B.D., Sharma, A., Sharma, G.D., Sharma, J.K. (2016). Study of genetic variability, character association, path analysis and selection parameters for heterotic recombinant inbred lines of garden peas (Pisum sativum var. Hortense L.) under mid- hill conditions of Himachal Pradesh, India. Legume Research; 39(2):163-169.

Kosev, V.I. (2015). Multivariate analysis of spring field pea genotypes. Banats journal of biotechnology 6(11):23-29.

Kumar, M., Jeberson, M.S., Singh, N.B., Sharma, R. (2017). Genetic Analysis of Seed Yield and Its Contributing Traits and Pattern Their Inheritance in Field pea (Pisum sativum L). International Journal of Current Microbiology and Applied Sciences; 6(6):172-181.

Majid, A., Dar, S.A., Wani, S.H., Bhat, M.A., Ambardar, V.K. and Lone, A.A. (2017). Genotype x Environment Interaction for Seed Yield and Protein Content in Fieldpea Genotypes under Kashmir Conditions. International Journal of Current Microbiology and Applied Sciences. (6)7. Pp. 3880-3884.

Mishra, R. (2014). Genetic variability and diversity analysis for improvement of yield and its related characters in field pea (Pisum sativum L.). Journal of Food Legumes 27 (3):255-257.

Panse, V.G. (1967). Shukhatme PV. Statistical methods for agriculture workers (2nd eds.). Indian Council of Agriculture Research, New Delhi.

Patel, (2016). Genetic Analysis of F1 Crosses of Bread Wheat Raised under Different Environments. Ph.D. thesis, JNKVV, Jabalpur.

Patel, (2017). Combining ability and heterosis studies for yield and its components in field pea (Pisum sativum L.). M.Sc. (Ag.) Thesis Indira Gandhi Krishi Vishwavidyalaya, Raipur (Chhattisgarh).

Rangnanna, S., (1986). Handbook of Analysis and quality control for fruit and vegetable products. 2nd Edition. Tata McGraw-Hill Publishing company lifted. New Deihi, India.

Sahoo, (2018). Genetic Analysis for Yield, Yield Components and Quality Traits in Pea. M.Sc. thesis, JNKVV, Jabalpur.

Saxena, R.R., Vidyakar, V., Vishwakarma, M.K., Yadav, P.S., Meena, M.L. and Lal, G.M. (2014). Genetic variability and heritability analysis for some quantitative traits in field pea (Pisum sativum L.). The Bioscan 9 (2): 895898.

Shelepina, N.V., Zelenov, A.N. and Bolshakova, L.S. (2016). Amino Acid Composition and Biological Value of Protein of New Pea Morphotypes. Indian Journal of Science and Technology, Vol 9(5).

Singh, B.D. (2002). Plant Breeding: Principles and Methods. Kalyani Publishers, New Delhi-Ludhiana, India.

Sivasubramanian, J. and Madhavamenon, P. (1973). Genotypic and phenotypic variability in rice. Madras Agricultural Journal 12: 15-16.

Toews, R. and Wang, N. (2013). Physicochemical and functional 
properties of protein concentrates. Food Research International 52:445-451.

Toppo, (2015). Genetic variability and character association analysis for seed quality and yield traits in field pea (Pisum sativum L.). M.Sc. (Ag.) Thesis. IGKVV, (Chhattisgarh).

Wuletaw, T. and Endashaw, B. (2003).

Variation and association of morphological and biochemical characters in grass pea (Lathyrus sativus L.). Euphytica 130: 315-324.

Yadav, S.K. (2013). Diallel cross analysis for yield and quality attributes in field pea (Pisum sativum L.). M. Sc. Thesis, IGKV, Raipur 88-90p.

\section{How to cite this article:}

Lokesh Gour, R.K. Dubey, P.K. Moitra, S.K. Singh, S.S. Shukla and Tiwari, S. 2018. Genetic Parameters Exploration of Pea Genotypes using Two Environmental Conditions. Int.J.Curr.Microbiol.App.Sci. 7(09): 2067-2078. doi: https://doi.org/10.20546/ijcmas.2018.709.252 